\title{
Tüketicilerin Sert Kabuklu Kuruyemiş Tüketim Alışkanlıkları ve Satın Alma Davranışlarının Belirlenmesi: Siirt İli Örneği
}

\author{
Merve Kardeş ${ }^{1}$, Koray Özrenk ${ }^{1}$, Mustafa Terin ${ }^{2 *}$ \\ ${ }^{1}$ Siirt Üniversitesi, Ziraat Fakültesi, Bahçe Bitkileri Bölümü, 56100 Siirt, Türkiye \\ ${ }^{2}$ Van Yüzüncü Yıl Üniversitesi, Ziraat Fakültesi, Tarım Ekonomisi Bölümü, 65080 Van, Türkiye
}

M A K A L E B İ L G İ S İ

Araştırma Makalesi

Geliș 14 Eylül 2017

Kabul 28 Aralık 2017

\section{Anahtar Kelimeler:}

Sert kabuklu kuruyemiş

Tüketim

Tüketici tercihleri

Logit model

Siirt

*Sorumlu Yazar:

E-mail: mustafaterin@yyu.edu.tr

\section{Ö Z E T}

Çalışmanın amacı, Siirt ili kentsel alanda tüketicilerin sert kabuklu kuruyemiş tüketim alışkanlıkları ve satın alma davranışlarını belirlemektir. Çalışmanın ana materyalini Siirt ili kentsel alanda yaşayan 150 tüketiciden anket yoluyla toplanan veriler oluşturmaktadır. Verilerin analizinde, frekans tabloları ve tüketicilerin ailelerinde yeterli miktarda kuruyemiş tüketip tüketmedikleri düşüncesi logit model yardımıyla analiz edilmiştir. Araştırmada, ankete katılanların \%62,7'si erkek, \%63,3’ü 25-40 yaş grubunda, \%64,0’ü evli, \%62,0'si 2001-4000 TL gelir grubunda, \%49,3'ü ailede yeterli miktarda kuruyemiş tüketildiği, \%56,0'sı kuruyemiş tüketiminin faydaları hakkında bilgiye sahip olduğu ve \%78,7'sinin kuruyemişi, kuruyemişçilerden satın aldığı belirlenmiştir. Çalışmada ayrıca ailede yeterli miktarda kuruyemiş tüketildiğini düşünme ile kuruyemiş tüketmenin faydalarını bilme arasında pozitif, cinsiyet arasında ise negatif bir ilişkini olduğu tespit edilmiştir.

Turkish Journal of Agriculture - Food Science and Technology, 6(2): 169-174, 2018

Determination of Consumers Hard Shelled Dried Nuts Consumption Habits and Purchase Behaviour: A Case of Siirt Province

\section{A R T I C LE IN F O}

\section{Research Article}

Received 14 September 2017 Accepted 28 December 2017

\section{Keywords:}

Hard shelled dried nuts

Consumption

Consumer preferences

Logit model

Siirt

\footnotetext{
*Corresponding Author:

E-mail: mustafaterin@yyu.edu.tr
}

\author{
A B S T R A C T
}

The aim of the study is to determine the consumers hard shell dried nuts consumption habits and purchasing behaviours in urban areas of Siirt Province. The main data of this study has been compiled through questionnaires from 150 consumers who live in urban area of Siirt. In the analysis of the data, frequency tables were used and the logit model where consumers consume sufficient amount of nuts in their families. In the survey, $62.7 \%$ of the respondents were male, $63.4 \%$ were in the $25-40$ age group, $64.0 \%$ were married, $62.0 \%$ were in the income group of $2001-4000 \mathrm{TL}, 49.3 \%$ of the family members consumed sufficient amount of nuts, $56.0 \%$ it was determined that the consumption of the nuts had information about the benefits and $78.7 \%$ of the nuts purchased from the nuts shop. In the study, it was also found that there was a positive relationship between think that sufficient amount of nuts was consumed in the family with knowing the benefits of nuts consumption On the other hand, the relationship between think that sufficient amount of nuts was consumed in the family and gender was found to be negative. 


\section{Giriş}

Kuruyemiş, yaş sebzenin kurutulması ve/veya kavrulmasıyla elde edilmektedir (Garipoğlu, 2006; Turan, 2012; Karcık, 2017). Türkiye sahip olduğu uygun coğrafi koşullar ve iklim itibariyle diğer tarım ürünlerinde olduğu gibi kuruyemiş sanayinin hammaddesi olan tarımsal ürünlerin (Fındık, fistık, badem, ceviz, Antep fistığı, incir, kayısı vb.) üretimi konusunda da oldukça şanslı konumdadır (Anonim, 2017). Türkiye, bu nedenle gerek kuruyemiş üretimi gerekse tüketimi açısından dünyanın önde gelen ülkeleri arasında yer almaktadır.

Eski çağlardan beri kuruyemiş tüketiminin insanların günlük beslenmesinde önemli bir yere sahip olduğu birçok çalışmada belirtilmiştir (He ve ark., 1998; Aranceta ve ark., 2006; Leong ve ark., 2011). Kuruyemişler günümüzde sağlıklı beslenmenin önemli bir bileşeni olarak görülmekte ve bilhassa badem, findık, ceviz, antepfistığı, yerfıstığı gibi çeşitler sadece besleyici olmaları sebebiyle değil tedavi edici ve insan sağlığına faydalı olmaları nedeniyle de sıklıkla tüketilmektedir. Önemli enerji kaynağı olmaları, çoğunlukla doymamış yă asitlerini içermeleri, genel olarak karbonhidrat, protein, vitamin, mineral maddeler, lif, bitkisel steroller bakımından zengin içeriklere sahip olmaları (Kelly ve Sabote, 2006; Kendall ve ark., 2010, Dreher, 2012) ve ayrica kandaki toplam kolesterol ile LDL konsantrasyonlarını ve lipoprotein vasitalı kardiyovasküler hastalıkları azaltmaları nedeniyle insan diyetinde yer alması gerektiği birçok çalışmada vurgulanmıştır (Dreher ve ark., 1996; Trichopoulou ve ark., 2005; Veloso ve ark., 2016).

Kuruyemiş tüketimi ile ilgili gerek yerli gerekse yabancı literatür incelendiğinde yapılan çalışmaların büyük çoğunluğunda kuruyemiş tüketiminin sağlık üzerine etkileri incelenirken (Sabate ve ark., 1993; Dreher ve ark., 1996; Trichopoulou ve ark., 2005; Kelly ve Sabote, 2006; Kendall ve ark., 2010, Dreher, 2012; Veloso ve ark., 2016), çok az sayıda yabancı literatürde tüketicilerin kuruyemiş (findık, fistık, badem, ceviz vb.) tüketim alışkanlıkları ve tercihlerini inceleyen çalışmalar yapılmıştır (He ve ark., 1998; Camarena ve Sanjuan, 2005; Aranceta ve ark., 2006; Leong ve ark., 2011). Yerli literatürde ise Turan (2012) tarafından Tekirdağ ilinde yapılan bir çalışma bulunmaktadır. $\mathrm{Bu}$ nedenle gerek hanelerin gerekse bireysel tüketicilerin kuruyemiş tüketim alışkanlıkları ve satın alma davranışlarını inceleyen yerel araştırmalara ihtiyaç olduğu söylenebilir.

Siirt ili sahip olduğu topoğrafik yapı ve iklim itibariyle sert kabuklu kuruyemiş (Siirt fistığı, badem, ceviz, menengiç ve buttum) yetiştiriciliğine uygun bir bölgedir. 2015 y1lı itibariyle Siirt ilinde yaklaşı 12 bin ton Siirt fistığ 1,212 ton badem ve 141 ton ceviz üretimi gerçekleştirilmiştir (Anonim, 2016). Siirt fistığı kadar bilinmemesine karşın ilde önemli miktarda menengiç ve buttum üretimi de yapılmaktadır. Menengiç, Türkiye'de doğal olarak yetişen bir bitki olup, tohumları protein, mineral, doymamış yă̆ asitlerince zengindir (Özcan, 2004). Kendine özgü tadı, kokusu ve yüksek aroma değerine sahip olan menengiç, ülkemizde ve bölgede genel olarak kahve ve çerez olarak tüketilmektedir. Buttum, Türkiye'de Gaziantep, Siirt, Hakkâri, Bitlis ve kısmen Mardin illerinde yoğun olarak bulunmaktadır.
Menengice oranla daha sert bir kabuğa sahip ve taneleri daha iridir, genellikle sabun üretimi ve kozmetikte kullanılmasına rağmen ilde çerez olarak ta tüketilmektedir. Menengiç ve buttum; kültür bitkisi olmadıklarından üretim değerlerine ulaşılamamıştır. Her iki tür de yörede yetişen Siirt çeşidine anaç olarak değerlendirilmektedir.

$\mathrm{Bu}$ bağlamda, Siirt ilinde yetiştirilen sert kabuklu kuruyemişlerin (Antep fistığı Siirt çeşidi, badem, ceviz, menengiç ve buttum) kentsel alandaki tüketiciler tarafından ne şekilde tüketildiği ve tüketicilerin satın alma davranışlarının belirlenmesi çalışmanın temel amacını oluşturmaktadır.

\section{Materyal ve Yöntem}

Çalışmanın ana materyalini, Siirt ili kentsel alanda yaşayan tüketicilerle (150 kişi) yüz yüze yapılan anket verileri oluşturmaktadır. Siirt İli Merkez ilçe kent nüfusu 2016 yılı TÜİK adrese dayalı nüfus sayımı sonuçlarına göre 147271 kişidir (TÜİK, 2017). Bu rakam araştırmanın ana kitlesini oluşturmaktadır. Örnek hacmi oransal örnekleme yöntemi kullanılarak (Miran, 2002) 150 olarak belirlenmiştir. Yöntemde $\% 95$ güven aralığı ve $\% 8$ hata payı kullanılmıştır.

$$
n=\frac{N \times p \times(1-p)}{(N-1) \times \sigma_{P}^{2}+p \times(1-p)}
$$

$\mathrm{n} \quad=$ Örnek hacmi

$\mathrm{N} \quad=$ Ana kitle (147271)

$\mathrm{P} \quad=$ Tahmin oranı (maksimum örnek hacmi için 0,5)

$\sigma_{\mathrm{p}}=$ Olasılık düzeyi güven aralığını (\%95 güven aralığı, 0,08 hata payı için $1,96 \sigma_{\mathrm{p}}=0,08$ eşitliğinden $\left.\sigma_{\mathrm{p}}=0,040816\right)$ ifade etmektedir.

$$
n=\frac{147271 \times 0.5 \times(1-0.5)}{(147271-1) \times(0.040816)^{2}+0.5 \times(1-0.5)}=150
$$

Çalışmada sert kabuklu kuruyemiş olarak, Siirt yöresinde yetişen Antep fistığı (Siirt çeşidi), badem, ceviz, menengiç ve buttum dikkate alınmıştır. Bu nedenle çalışmanın ileriki bölümlerinde set kabuklu kuruyemiş ile belirtilmek istenen Siirt yöresinde yetişen Antep fistığ (Siirt çeşidi), badem, ceviz, menengiç ve buttum'dır. Anket çalışması ağırlıklı olarak Siirt ilinin en işlek caddesi olan Güres Caddesinde, alışveriş merkezlerinde, kamu kurum ve kuruluşlarında yapılmıştır.

Verilerin analizinde, frekans tabloları ile tüketicilerin ailede yeterli miktarda sert kabuklu kuruyemiş tüketip tüketmediklerine etki eden faktörler "sınırlı bağımlı değişken" regresyon modeli (Logit tahmin yöntemi) kullanılarak tespit edilmiştir (Gujarati, 2005).

Çalışmada tüketicilerin yeterli miktarda sert kabuklu kuruyemiş tüketip tüketmediklerini düşünme durumu sınırlı bağımlı değişken olarak belirlenmiştir. Yeterli miktarda sert kabuklu kuruyemiş tükettiğini düşünenler " 1 ” tüketmediğini düşünenler " 0 " ile kodlanmıştır. Logit modeli aşağıdaki şekilde ifade edilmektedir (Greene, 2012). 


$$
\begin{aligned}
& P_{i}=E\left(Y=1 \mid X_{i}\right)=\alpha+\beta X_{i} \\
& P_{i}=E\left(Y_{i}=1 \mid X_{i}\right)=\frac{1}{1+e^{-\left(\alpha+\beta X_{i}\right)}}=\frac{1}{1+e^{-Z_{i}}}
\end{aligned}
$$

Burada: $Z=\alpha+\beta X_{i}$

$P_{i}$ : Açıklayıcı değişken $\left(\mathrm{X}_{\mathrm{i}}\right)$ hakkında bilgi verirken inci bireyin belirli bir tercihi yapma olasılığını ifade etmektedir. Model, k serbestlik derecesine sahip LR (k) (Likelihood Ratio: olabilirlik oranı) testi ile test edilebilir.

\section{Araştırma Bulguları ve Tartışma}

\section{Sosyo Demografik Özellikler}

Ankete katılan tüketicilerin sosyo demografik özelliklerine ait tanımlayıcı istatistikler Çizelge 1'de verilmiştir. Buna göre tüketicilerin \%62,7'si erkek, $\% 63,3$ 'ü 25-40 yaş grubunda, \%69,3'ü üniversite mezunu, \%64,0’1 evli ve \%62,0'si 2001-4000 TL aras1 gelire sahiptir. Malezya'da yapılan çalışmada tüketicilerin $\% 35,4$ 'ünün erkek, \%67,1'inin 31-50 yaş grubu arasında, $\% 13,2$ 'sinin üniversite mezunu, \%69,2'sinin evli olduğu (Leong ve ark., 2011), İspanya'da yapılan çalışmada tüketicilerin \%46'sının erkek, \%67,0'sinin 40 yaşından küçük ve \%74,0'ünün üniversite mezunu olduğu (Camarena ve Sanjuan, 2005), Tekirdağ'da yapılan çalışmada da tüketicilerin \%45,41'inin erkek, \%61,05'i 26-45 yaş grubu arasında, \%57,48'inin evli ve $\% 46,71$ 'inin üniversite mezunu olduğu tespit edilmiştir (Turan, 2012). Araştırma sonuçları ile literatür arasında benzerliklerin olduğu söylenebilir.

Çizelge 1 Ankete katılanların sosyo demografik özellikleri Table 1 Socio-demographic characteristics of respondents

\begin{tabular}{l|cc}
\hline \multicolumn{1}{c|}{ Değişkenler } & Frekans & $\%$ \\
\hline Cinsiyet & & \\
Erkek & 94 & 62,7 \\
Kadın & 56 & 37,3 \\
Yaş & & \\
18-24 & 16 & 10,7 \\
$25-40$ & 95 & 63,3 \\
41-60+ & 39 & 26,0 \\
Eğitim & & \\
İlköğretim & 22 & 1,3 \\
Lise & 22 & 14,7 \\
Ön lisans & 104 & 69,3 \\
Lisans & & \\
Medeni Durum & 96 & 64,0 \\
Evli & 54 & 36,0 \\
Bekâr & & \\
Gelir (TL/Ay) & 21 & 14,0 \\
<2000 TL/Ay & 93 & 62,0 \\
2001-4000 TL/Ay & 36 & 24,0 \\
4001+ TL/Ay & & \\
\hline
\end{tabular}

Sert Kabuklu Kuruyemiş Tüketim Alışkanlıkları ve Satın Alma Davranışları

Ankete katılan tüketicilerin aylık Antep fistığı (Siirt çeşidi), badem, ceviz, menengiç ve buttum tüketim miktarları Çizelge 2'de verilmiştir. Tüketicilerin tamamı Siirt fistığ1 tüketirken, \%27,3'ü buttum, \%26,7'si menengiç, \%6,7'si badem ve \%4,0'ü ise ceviz tüketmemektedir. Menengiçin ağırlıklı olarak kahve şeklinde, buttumında ağırlıklı olarak kozmetik (sabun yapımı) alanında kullanılıyor olması bu iki ürünün diğer sert kabuklu kuruyemişlere göre daha az çerezlik olarak tüketilmesine neden olduğu söylenebilir ki araştırma sonuçları da bunu desteklemektedir.

Tüketicilerin tamamı Siirt fistığını tüketmektedir. Siirt fıstığının ilin en önemli tarımsal ürünü olması, alternatifi olan badem ve cevize göre nispeten fiyatlarının azda olsa düşük olması bunun yanı sıra tüketicilerin yerel ürünlerine sahip çıkma isteği, yıllardır oluşan tüketim alışkanlıkları ve damak tadı gibi faktörlerin Siirt fistığının tüketicilerin tamamı tarafindan tercih edilmesinde etkili olduğu söylenebilir. Nitekim araştırmada tüketicilerin \%82,0'si Siirt fistığının diğer sert kabuklu kuruyemişlere göre daha fazla tercih edildiğini düşünmektedir (Çizelge 3). Tüketicilerin her bir sert kabuklu kuruyemişte aylık ağırlıklı olarak 100 gr'dan az ve 101- 500 gr arasında tüketimi tercih ettikleri söylenebilir (Çizelge 2).

Ankete katılan tüketicilerin \%49,3'ü ailede yeterince sert kabuklu kuruyemiş tüketildiğini \%50,7'si tüketilmediğini düşünmektedir. Ailede yeterince sert kabuklu kuruyemiş tüketilmediğini düşünen ailelerin \%43,4'ü alışkanlıklarının fazla olmadığı, \%34,2'si fiyatların yüksek olduğu, \%19,7'si gelirinin sınırlı olduğu ve \%2,7'si sağlı sorunları nedeniyle yeterince sert kabuklu kuruyemiş tüketmediklerini belirtmiştir (Çizelge 3). Tüketicilerin \%56,0'sı kuruyemiş tüketiminin faydaları hakkında bilgiye sahip olduğunu belirtmiştir. Tüketicilerin \% 78,7'i kuruyemişi kuruyemişçilerden, $\% 13,3$ 'ü süper ve hiper marketlerden ve $\% 8,0$ 'i üreticilerden satın almaktadır. Satın alınan yerin tercih edilmesinde satılan ürünlerin sırasıyla kaliteli, taze, lezzetli ve fiyatlarının ulaşılabilir olması önemli kriterler olarak tespit edilmiştir. Turan ve ark (2014) tarafindan Tekirdağ ilinde yapılan çalışmada tüketicilerin \%46,11'inin kuruyemişi, kuruyemişçilerden, \%29,34'ünün süper ve hiper marketlerden, \%13,77'sinin bakkallardan, Leong ve ark (2011) tarafından Malezya'da yapılan çalışmada da tüketicilerin kuruyemişi \%34,9'unun süper ve hiper marketlerden, \%26,1'inin bakkallardan ve \%9,7'sinin seyyar satıcılarda satın aldıklarını tespit etmişlerdir. Araştırma sonuçları ile literatür arasında birtakım farkların olduğu söylenebilir. Siirt ilinde kuruyemiş sektörünün Siirt fistığının ilde üretilmesi nedeniyle gelişmiş olması, tüketicilerin ağırlıklı olarak kuruyemiş satın alırken kuruyemişçileri tercih etmesinde etkili olduğu söylenebilir.

Tüketicilerin \%34,0’ü ambalajlı kuruyemişlerin daha sağlıklı olduğunu, \%43,3’ü ise daha sağlıklı olmadığını düşünmektedir (Çizelge 3). Nitekim araştırmada tüketicilerin kuruyemiş satın alma tercihini en az etkileyen faktörün, her bir sert kabuklu kuruyemiş için (Siirt fistığı, badem, ceviz, menengiç ve buttum) ambalaj olduğu belirlenmiştir (Çizelge 4). Tekirdağ ilinde yapılan benzer çalışmada da tüketicilerin kuruyemiş satın alırken dikkate aldıkları kriterler arasında ambalaj son sırada yer almıştır (Turan ve ark., 2014).

Tüketicilerin sert kabuklu kuruyemiş satın alırken dikkate aldığı kriterler 5'li likert ölçeği kullanılarak değerlendirilmiş ve sonuçları Çizelge 4'te verilmiştir. Buna göre tüketicilerin sert kabuklu kuruyemiş satın alırken dikkat ettiği en önemli kriter; Antep fistığı (Siirt çeşidi), badem ve cevizde tazelik $(4,56 ; 4,31$ ve 4,39$)$ iken, menengiç ve buttumda lezzet $(3,21$ ve 3,13$)$ olarak 
belirlenmiştir. Her bir üründe en az etkiye sahip olan kriterin ise ambalaj olduğu belirlenmiştir (Çizelge 4). Tekirdağ ilinde yapılan benzer çalışmada da tüketicilerin kuruyemiş satın alırken dikkate aldığı en önemli kriter tazelik iken, en az öneme sahip kriterin ambalaj olduğu tespit edilmiştir (Turan ve ark., 2014).

\section{Lojistik Regresyon Analiz Sonuçları}

Lojistik regresyon analizinde kullanılan değişkenlere ait istatistiki özetler Çizelge 5'te verilmiştir. Regresyon analiz sonuçlarına göre model istatistiki açıdan anlamalıdır (Çizelge 6). Bu sonuçlara göre ankete katılan tüketicilerin ailelerinde kuruyemiş tüketim miktarını yeterli bulması ile kuruyemiş tüketmenin faydalarını bilme, Siirt ilinde kuruyemişçilik anlayışının iyi olduğunu düşünme, tüketilen kuruyemişin kalitesinin fiyatını karşıladığını düşünme arasında pozitif, cinsiyet arasında ise negatif bir ilişkinin olduğu tespit edilmiştir.
Tüketicilerin erkek olması, (kadınlara göre) ailelerinde kuruyemiş tüketim miktarını yeterli bulmama olasılığını arttırmaktadır. Erkek olmak ailede tüketilen kuruyemiş miktarını yeterli bulma olasılığını 1.85 kat azaltmaktadır. Diğer bir ifade ile kadınlar ailelerinde kuruyemiş tüketim miktarını yeterli olduğunu düşünürken, erkekler yeterli olduğunu düşünmemektedir. He ve ark (1998) tarafindan Amerika'da yapılan çalışmada cinsiyetin aperatif olarak findık tüketimine etki ettiği, erkeklerin kadınlara göre aperatif olarak fındık tüketme olasılığının daha yüksek olduğunu belirtmiştir.

Kuruyemiş tüketiminin faydasını bilmek (bilmeyenlere göre), Siirt'te kuruyemişçilik anlayışının iyi olduğunu düşünmek (iyi olmadığını düşünenlere göre) ve kaliteli kuruyemişin fiyatını karşıladığını düşünmek (düşünmeyenlere göre) ailede yeterli miktarda kuruyemiş tüketildiğini düşünme olasılığını sırasıyla $0,19,0,20$ ve 0,18 kat arttırmaktadır (Çizelge 6).

Çizelge 2 Tüketicilerin aylık sert kabuklu kuruyemiş tüketim miktarları

Table 2 Monthly consumption quantities of hard-shelled dried nuts by consumers

\begin{tabular}{|c|c|c|c|c|c|c|c|c|c|c|}
\hline \multirow{3}{*}{$\begin{array}{l}\text { Tüketim miktarı } \\
\text { (Gr/Ay) }\end{array}$} & \multicolumn{10}{|c|}{ Ürünler } \\
\hline & \multicolumn{2}{|c|}{ Antep fistığ $1^{*}$} & \multicolumn{2}{|c|}{ Badem } & \multicolumn{2}{|c|}{ Ceviz } & \multicolumn{2}{|c|}{ Menengiç } & \multicolumn{2}{|c|}{ Buttum } \\
\hline & $\mathrm{N}$ & $\%$ & $\mathrm{~N}$ & $\%$ & $\mathrm{~N}$ & $\%$ & $\mathrm{~N}$ & $\%$ & $\mathrm{~N}$ & $\%$ \\
\hline Hiç tüketmeyen & 0 & 0,0 & 10 & 6,7 & 6 & 4,0 & 40 & 26,7 & 41 & 27,3 \\
\hline$\leq 100 \mathrm{gr}$ & 51 & 34,0 & 60 & 40,0 & 49 & 32,7 & 79 & 50,7 & 74 & 49,3 \\
\hline $101-500 \mathrm{gr}$ & 53 & 35,3 & 54 & 36,0 & 54 & 36,0 & 32 & 21,3 & 31 & 20,7 \\
\hline $501-1000 \mathrm{gr}$ & 22 & 14,7 & 17 & 11,3 & 27 & 18,0 & 2 & 1,3 & 1 & 0,7 \\
\hline $1001+\mathrm{gr}$ & 24 & 16,0 & 9 & 6,0 & 14 & 9,3 & 0 & 0,0 & 3 & 2,0 \\
\hline Toplam & 150 & 100,0 & 150 & 100,0 & 150 & 100,0 & 150 & 100,0 & 150 & 100,0 \\
\hline
\end{tabular}

*Siirt çeşidi

Çizelge 3 Tüketicilerin sert kabuklu kuruyemiş tüketim ve satın alma davranışları Table 3 Hard-shelled dried nuts consumption of consumers and purchase behavior

\begin{tabular}{|c|c|c|}
\hline Değişkenler & Frekans & $\%$ \\
\hline \multicolumn{3}{|l|}{ Ailede yeterince kuruyemiş tüketilme durumu } \\
\hline Evet & 74 & 49,3 \\
\hline Hayır & 76 & 50,7 \\
\hline \multicolumn{3}{|l|}{ Ailede yeterince kuruyemiş tüketilmeme nedeni } \\
\hline Alışkanlığımız fazla yok & 33 & 43,4 \\
\hline Kuruyemiş fiyatları yüksek & 26 & 34,2 \\
\hline Gelir sinırlı & 15 & 19,7 \\
\hline Sağlik vb. & 2 & 2,7 \\
\hline \multicolumn{3}{|c|}{ Kuruyemiş tüketmenin faydaları hakkında bilgi sahibi olma durumu } \\
\hline Evet & 84 & 56,0 \\
\hline Hayır & 66 & 44,0 \\
\hline \multicolumn{3}{|l|}{ Kuruyemişin satın alındığı yerler } \\
\hline Marketler & 20 & 13,3 \\
\hline Kuruyemişçiler & 118 & 78,7 \\
\hline Üreticiler & 12 & 8,0 \\
\hline \multicolumn{3}{|c|}{ Ambalajlı kuruyemişin daha sağlıklı olduğunu düşünme } \\
\hline Evet & 51 & 34,0 \\
\hline Hayır & 65 & 43,3 \\
\hline Kararsızım & 34 & 22,7 \\
\hline \multicolumn{3}{|c|}{ Siirt ilinde Siirt fistığı diğer sert kabuklulara göre daha çok mu tercih ediliyor } \\
\hline Evet & 123 & 82,0 \\
\hline Hayır & 21 & 14,0 \\
\hline Kararsızım & 6 & 4,0 \\
\hline
\end{tabular}


Çizelge 4 Tüketicilerin sert kabuklu kuruyemiş satın alırken tercihlerini etkileyen faktörler

Table 4 Factors affecting preferences of consumers purchasing hard-shelled dried nuts

\begin{tabular}{|c|c|c|c|c|c|c|c|c|c|c|}
\hline \multirow{3}{*}{ Kriterler } & \multicolumn{10}{|c|}{ Ürünler } \\
\hline & \multicolumn{2}{|c|}{ Antep fistı ${ }_{1} *$} & \multicolumn{2}{|c|}{ Badem } & \multicolumn{2}{|c|}{ Ceviz } & \multicolumn{2}{|c|}{ Menengiç } & \multicolumn{2}{|c|}{ Buttum } \\
\hline & Ort. & Std.S & Ort. & Std.S & Ort. & Std.S & Ort. & Std.S & Ort. & Std.S \\
\hline Fiyat & 3,89 & 1,28 & 3,63 & 1,50 & 3,75 & 1,44 & 2,67 & 1,95 & 2,59 & 1,97 \\
\hline Kalite & 4,51 & 0,92 & 4,17 & 1,38 & 4,30 & 1,27 & 3,09 & 2,08 & 3,09 & 2,13 \\
\hline Lezzet & 4,52 & 0,80 & 4,26 & 1,31 & 4,38 & 1,21 & 3,21 & 2,12 & 3,13 & 2,15 \\
\hline Tazelik & 4,56 & 0,83 & 4,31 & 1,30 & 4,39 & 1,22 & 3,19 & 2,10 & 3,09 & 2,12 \\
\hline Sağlıklı olma & 4,49 & 0,86 & 4,26 & 1,36 & 4,30 & 1,30 & 3,17 & 2,11 & 3,10 & 2,14 \\
\hline Ambalaj & 3,12 & 1,37 & 2,87 & 1,45 & 3,05 & 1,46 & 2,09 & 1,63 & 2,04 & 1,64 \\
\hline Yerel ürün olması & 3,76 & 1,44 & 3,26 & 1,61 & 3,37 & 1,57 & 2,49 & 1,94 & 2,48 & 1,97 \\
\hline
\end{tabular}

*Siirt çeşidi; (1: Hiç önemli değil, 2: Az önemli, 3: Önemli, 4: Oldukça önemli, 5: Çok önemli)

Çizelge 5 Logit modele ait değişkenlerin tanımlanması ve istatistiki özetler

Table 5 Ingilizce başlık

\begin{tabular}{l|c}
\hline \multicolumn{1}{c|}{ Değişkenler } & Değerler \\
\hline Bağımlı değişken & $\% 49,3$ \\
Ailede yeterli miktarda kuruyemiş tüketildiğini düşünme (Evet 1; Hayır 0) & Değerler \\
Bağımsız değişkenler & $\% 62,7$ \\
$\quad$ Cinsiyet (Erkek 1; Kadın 0) & $\% 26,0$ \\
Yaş grubu 41-60+ yaş grubu 1; diğer yaş grupları, 0 & $\% 14,0$ \\
Gelir & $\% 62,0$ \\
$\leq 2000$ TL/Ay $\quad$ (Evet 1; Hayır 0) (Referans grup) & $\% 24,0$ \\
2001-4000 TL/Ay (Evet 1; Hayır 0) & $\% 56,0$ \\
4001+ TL/Ay $\quad$ (Evet 1; Hayır 0) & $\% 38,7$ \\
Kuruyemişin faydaları hakkında bilgi sahibi olma (Evet 1; Hayır 0) & $\% 38,0$ \\
Siirt ilinde kuruyemişçilik anlayışı ( İyi 1; Kötü 0) & \\
Tüketilen kuruyemişin kalitesinin fiyatını karş1laması (Evet 1; Hayır 0) & \\
\hline
\end{tabular}

Çizelge 6 Lojistik regresyon analizi sonuçları

Table 6 Definitions of variables and statistical summaries of Logit Model

\begin{tabular}{l|cccc}
\multicolumn{1}{c|}{ Değişkenler } & Katsayılar & Std. Hata & P değeri & Marjinal etki \\
\hline Sabit & $-1,180$ & 0,639 & $0,065^{*}$ & ------- \\
Cinsiyet & $-0,906$ & 0,400 & $0,024^{* *}$ & $-1,857$ \\
Yaş_3 (41-60+) & 0,520 & 0,430 & 0,227 & 0,105 \\
Gelir_2 (2000-4000 TL/Ay) & 0,569 & 0,552 & 0,303 & 0,115 \\
Gelir_3 (4001+ TL/Ay) & 0,023 & 0,633 & 0,971 & 0,005 \\
Kuruyemiş tüketmenin faydasını bilme & 0,927 & 0,385 & $0,016^{* *}$ & 0,191 \\
Siirt kuruyemişçilik anlayış1 & 0,975 & 0,388 & $0,012^{* *}$ & 0,204 \\
Kalite-fiyat & 0,852 & 0,383 & $0,026^{* *}$ & 0,177
\end{tabular}

McFadden R-Squared: 0,156; Loglikelihood: $-87,748 ; X^{2}(7): 32,422^{* * *}$

***\%1, **\%5 ve *\%10 düzeyinde anlamlıdır.

\section{Sonuç ve Öneriler}

Çalışmada, Siirt ili kentsel alanda yaşayan tüketicilerin sert kabuklu kuruyemiş tüketim alışkanlıkları ve satın alma davranışlarının belirlenmesi amaçlanmıştır. Araştırma sonuçlarına göre; tüketicilerin tamamı Siirt fistığı tüketirken, \%27,3'ü buttum, \%26,7'si menengiç, $\% 6,7$ 'si badem ve \%4,0'ü ise ceviz tüketmediği tespit edilmiştir. Tüketicilerin her bir sert kabuklu kuruyemişte aylık ağırlıklı olarak 100 gr'dan az ve 101-500 gr arasında tüketimi tercih ettiği belirlenmiştir. Tüketicilerin yaklaşık olarak yarısının ailesinde yeterli miktarda kuruyemiş tüketilmemektedir. Tüketicilerin birçoğu kuruyemişi kuruyemişçilerden satın almaktadır. Tüketiciler kuruyemiş satın alırken en fazla tazeliğine en az ambalaja önem vermektedir.

Lojistik regresyon sonuçlarına göre; kuruyemiş tüketmenin faydalarını bilme, Siirt ilinde kuruyemişçilik anlayışının iyi olduğunu düşünme, tüketilen kuruyemişin kalitesinin fiyatını karşıladığını düşünme, ailede tüketilen kuruyemiş miktarının yeterli olduğunu düşünme olasılığını yükseltirken; cinsiyet (erkek olmak) bu olasılığı düşürmektedir.

Araştırmadan elde edilen sonuçlar, kuruyemişlerin büyük paketlerden ziyade daha küçük paketler halinde tüketime sunulması, kuruyemişlerin taze ve lezzetli olmasının fiyattan daha önemli olduğunu, ambalajın kuruyemiş tercihinde önemli bir faktör olmadığını, kuruyemiş tüketiminin faydalarını bilmenin tüketimi arttırdığını ve tüketicilerin sahip olduğu sosyo demografik özelliklerin kuruyemiş tüketim alışkanlıklarını etkilediğini ortaya koymuştur. $\mathrm{Bu}$ sonuçlardan hareketle özellikle kuruyemiş perakende sektöründe yer alan işletmelerin bu sonuçları dikkate alarak tüketicilere ürün arz etmesi gerek tüketiciler gerekse firmalar için kazançlı olacaktır. 


\section{Kaynaklar}

Anonim. 2016. Siirt İl Gıda, Tarım ve Hayvancılık Müdürlüğü Kayitlar1

Anonim. 2017. Kuruyemiş sektör raporu. Ankara Ticaret Borsas1. http://www.ankaratb.org.tr/lib_upload/Kuruyemi\% C5\%9F\%20Sekt\%C3\%B6r\%C3\%BC.pdf Erişim: 07.09.2017.

Aranceta J, Rodrigo CP, Naska A, Vadillo VR, Trichopoulou A. 2006. Nut consumption in Spain and other countries. British Journal of Nutrition, 96 (2): 3-11.

Camarena DM. Sanjuan AI. 2005. Walnut preferences in Spain: Is the Spanish consumer ready for new varieties? $\mathrm{XI}^{\text {th }}$ Congress of the European Association of Agricultural Economists (EAAE), 24-27 August 2005, Copenhagen, Denmark.

Dreher ML, Maher CV, Kearny P. 1996. The traditional and emerging role of nuts in healthful diets. Nutrition Reviews, 54 (8): 241-245.

Dreher ML. 2012. Pistachio nuts: composition and potential health benefits. Nutrition Reviews, 70 (4): 234-240.

Garipoğlu H. 2006. Bazı Baharat ve Kuruyemişlerin Aflatoksin İçeriğinin Belirlenmesi Üzerine Bir Araştırma. Trakya Üniversitesi, Fen Bilimleri Enstitüsü, yüksek lisan tezi, Tekirdağ.

Greene WH. 2012. Econometric Analysis. Seventh Edition. Pearson Prentice-Hall, Upper Saddle River, New Jersey, 07458. ISBN 10:0-13-139538-6

Gujarati DN. 2005. Temel Ekonometri. Literatür Yayıncılık, 540-578, İstanbul.

He S, Fletcher S, Rimal A. 2005. Snack peanut consumption: Type preference and consumption manners. Journal of Food Distribution Research 36 (1): 79-85.

He S, Florkowski WJ, Elnagheeb AH. 1998. Consumer characteristics Influencing the consumption of nutcontaining Products. Journal of Food Distribution Research 29(July):31-44.

Karcık H. 2017. Çeşitli organik kuruyemişlerin ağır metal içeriklerine yönelik bir araştırma. Namık Kemal Üniversitesi, Fen Bilimleri Enstitüsü, yüksek lisans tezi, Tekirdağ.
Kelly JH, Sabate J. 2006. Nuts and coronary heart disease: An epidemiological perspective. British Journal of Nutrition, 96 (2): 61-67.

Kendall CWC, Esfahani A, Truan J, Srichaikul K, Jenkis DJA. 2010. Health benefits of nuts in prevention management of diabetes. Asia Pacific Journal of Clinical Nutrition, 19 (1): 110-116.

Leong YH, Ismail N, Latiff AA, Nurul Izzah A, Narazah MY, Nuru lain AB. 2011. Nuts consumption pattern among Malaysian adults: a socio demographic and dietary behavior perspective. International Food Research Journal, 18: 319328.

Miran B. 2002. Temel İstatistik. İzmir.

Özcan M. 2004. Characteristics of fruit and oil of terebinth (Pistaciaterebinthus L) growing wild in Turkey. Journal of the Science of Food and Agriculture, 84: 517-520

Sabate J, Fraser GE, Burke K, Knutsen SF, Bennett H, Linsted KD. 1993. Effects of walnuts on serum lipid levels and blood pressure in normal men. The New England Journal of Medicine, 328 (9): 603-607

Trichopoulou A, Naska A, Orfanos Ph, Trichopoulos D. 2005. Mediterranean diet in relation to body mass index and waisttohip ratio: the Greek European Prospective Investigation into Cancer and Nutrition Study. American Journal of Clinical Nutrition, 82: 935-940.

Turan DÇ. 2012. Türkiye'de kuruyemiş sektörü, firmalar arası rekabet stratejileri ve tüketici eğilimleri. Namık Kemal Üniversitesi, Fen Bilimleri Enstitüsü, yüksek lisans tezi Tekirdağ.

Turan DÇ, Güngör H, Güngör G. 2014. Türkiye'de kuruyemiş sektörü ve tüketicilerin satın alma davranışları: Tekirdağ ili örneği. XI. Ulusal Tarım Ekonomisi Kongresi bildiriler kitabı, s. 1474-1480. 3-5 Eylül 2014, Samsun.

TÜİK 2017. Türkiye İstatistik Kurumu http://www.tuik.gov.tr/ PreTablo.do?alt_id=1059 Erişim: 06.02.2017.

Veloso KM, Paulionis L, Poon T, Lee HY. 2016. The effects of almond consumption on fasting blood lipid levels: a systematic review and meta-analysis of randomized controlled trials. Journal of Nutritional Science, 5 (35): 1-15. 